\title{
Sivistysteoreettinen Oulu
}

Ari Kivelä ja Ari Sutinen (toim.). Teoria ja traditio. Juhlakirja Pauli Siljanderille. Suomen Kasvatustieteellinen Seura 2009.

Toisen maailmansodan jälkeen Suomi käänsi selkänsä sekä moraalisen että aineellisen konkurssin kärsineelle keskiselle Euroopalle ja kurottui kohti valtameren takaista voittajaa. Fullbrightstipendien siivittämänä alkoi suomalainen tiede-elämä vähin erin amerikkalaistua. Tieteellinen totuus seuraa muutoksia poliit- tisissa ja taloudellisissa voimasuhteissa niin kyyniseltä kuin se kuulostaakin. Vielä äsken hallinneesta tieteellisesta traditiosta tulee epätosi. Jos joku vielä ottaa sellaisen vakavasti, kohoavat kulmakarvat ympärillä.

Pauli Siljander on tällainen vastarannan kiiski. Hän luki itsensä sisään henkitieteelliseen pedagogiikkaan aikana, joka näki saksalaisen kasvatustieteen vain osana hävettävää ja onneksi jo taakse jäänyttä menneisyyttä. Nohl, Weniger, Litt ynnä muut saivat osakseen Pauli Siljanderin arvostavan analyysin. Matka jatkui henkitieteellisen pedagogiikan sisäisen kehityksen myötä kriittiseen kasvatustieteeseen. Pauli Siljander oli kyllin karismaattinen vetääkseen muitakin epäajanmukaiseen projektiin- 
sa. Syntyi Oulun koulu, se jota muualla Suomessa katsotaan hiukan ihmetellen mutta myös ihaillen.

Oulun koulun tavaramerkkinä on innostus sivistysteoriaan. Koulu profiloitui ennen kuin profiloitumisesta tuli hallinnollisten kehittämissuunnitelmien vakiovaatimus. Nyt ilmestynyt juhlakirja on sekä kokoava katsaus Oulun koululle itselleen että koulun esittely muille. Ari Kivelän ja Ari Sutisen johdantojakso kytkee erinomaisesti yksittäiset artikkelit olennaisiin keskusteluteemoihin. Kysymys on siis ennen kaikkea sivistyksestä.

\section{K} ikki toki tietävät, mitä sivistys on, mutta tämän arjen käsityksen kirjan kirjoittajat ylittävät huikealla problematisoinnillaan. On pidettävä lujasti kiinni, ettei putoa kärryiltä. Yhtenä kirjan lukijana minä tulin ajatelleeksi Marxin Feuerbach -teesejä vuodelta 1845. Marx huomautti, että jos seurataan sitä materialistista oppia, jonka mukaan ihmiset ovat olosuhteiden ja kasvatuksen tulosta, täytyy muutosagentin tulla jostakin yhteiskunnan ulkopuolelta. Sieltä vain ei tule mitään eikä ketään ihmistä muuttamaan, jolloin jäljelle jää vain se, että ihmisen on muututtava muuttaessaan olosuhteitaan. Ihminen muuttuu harjoittaessaan kumouksellista käytäntöä. Mutta mikä hänet siihen ajaa? Ilmeisesti ristiriita vallitsevan maailman ja oivallettujen mahdollisuuksien välillä. Ihmisen olemisen tapaan kuuluu mahdollisuus vallitsevan ja saavutetun ylittämiseen. Muutos tapahtuu samanaikaisesti sekä yleisellä että yksilöllisellä tasolla.

Mitä ihmisestä muutosprosessissa tulee? Sivistysteoreetikot ovat tässä suhteessa tar- koituksellisen vaiteliaita, ihminen kun on vielä olemukseltaan arvoitus. Ihminen muotoutuu sivistysprosessissa, mutta sen tavoitteita ei ole lupa lyödä kiinni. Saa nähdä mitä ihmisestä tulee. Usein kuitenkin sanotaan, että sivistyminen on emansipaatiota. Vapautumista mistä ja mihin ? Vapautumista kausaalisista irrationaalisista sidoksista, sanotaan. Sivistymisen tuloksena ihminen elää aikaisempaa rationaalisemmin. Onko raja-arvona se Kantin mainitsema täysin rationaalinen olento, joka ei tarvitse moraalia normin muodossa, koska toimii ilman muuta moraalilain mukaan ? Ehkä lopulta emansipoidumme ruumiista ja sen vulgaareista vaatimuksista olennoiksi, jotka ovat pelkästään rationaalista ajattelua. Näin pitkälle ei sentään mennä, kun tavoitteeksi asetetaan "kypsyys", joka sekin on ajatuksena Kantin peruja.

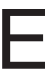
äs keskeinen sivistymisen elementti, suorastaan sen ehto, on vastavuoroinen tunnustaminen. Standardiesityksissä tunnustamisen idea sijoitetaan Hegelin nimiin. Nykykeskusteluun sen ovat tuoneet Habermas, Apel ja Honneth. Tunnustamisen merkitys on siinä, että tunnustetaan toisen vapaus ja luovuus, myönnetään että hän on samoin oikeuksin toimiva subjekti. Subjektit kykenevät vastavuoroisesti asettumaan toistensa asemaan. Tässä ihanteessa on jotakin hyvin vetoavaa ja niinpä pettymys onkin ollut ilmeinen, kun kasvatussuhde ei tahdo siihen taipua. Kasvatilla ei ole samaa kulttuurista kompetenssia kuin kasvattajalla eikä hän välttämättä ymmärrä pedagogista intentiota. Toteutuuko mainittu ihanne yleisesti aikuisten keski- näisissä suhteissa ? Nyky-yhteiskunnassa on tavallista nähdä toiset ihmiset välineinä omassa elämänprojektissa. Silloin on tärkeää peittää omat tavoitteet ja samalla luoda illuusio yhteisymmärryksestä. Toinen ei tietenkään silloin ole tasavertainen subjekti itsen kanssa. Arkikielessä asetelmaa kutsutaan huijaamiseksi. Tapahtuuko kuvatunlaisissa suhteissa jotakin, joka on sivistymisprosessille käänteinen? Tätä ja muita sivistymisen ulottuvuuksia tarkastelevat artikkeleissaan ansiokkaasti Kimmo Kontio (Rousseau), Mari Mielityinen (Schleiermacher), Ari Kivelä (Mollenhauer) sekä Teemu Hanhela (Honneth). On hienoa, että Hegelin varjoon eiansaitusti jäänyt Schleiermacher saa nykyisin tunnustusta omintakeisesta ajattelustaan.

Nilsiän kirkolla on jyhkeä muistomerkki Paavo Ruotsalaisen kunniaksi. Sen jalustaan on kaiverrettu seppä Högmanin tunnetut sanat Paavo Ruotsalaiselle: "Ystäväni yksi sinulta puuttuu ja sen mukana kaikki: Kristuksen sisäinen tunto." Se joka tuon tunnon saavuttaa, kokee uudestisyntymisen, hänen elämänsä saa kokonaan uuden laadun. Michael Uljens käyttää uudestisyntymisen ideaa kuvatessaan yksilön sivistysprosessia. Kysymyksessä on suhteessa alkuperäiseen ideaan toiseen elämänpiiriin sijoitettu malli. Sivistyminen esitetään uudestisyntymisten sekvenssinä. Viimeinen askel olisi yksilön siirtyminen ajasta iäisyyteen, mutta sen Uljens tieteenharjoittajana jättää tarkastelun ulkopuolelle. Suvereenilla otteella kirjoitetussa artikkelissa Uljens ottaa kantaa myös viime vuosikymmenten pyrkimykseen tehdä pesäero subjektiteoreettiseen ajatteluun. 
Intersubjektivistista perustaa on haettu milloin Heideggerilta, milloin Habermasilta, milloin Levinakselta. Uljens näkee subjektiivisten ja intersubjektiivisten elementtien vuorottelevan yksilön sivistysprosessissa. Pitäisikö puhua jonkinlaisesta dialektiikasta, vaikka sana onkin melkoisen kuormitettu?

Eetu Pikkarainen kysyy ontologian relevanssia kasvatustieteellisessä tutkimuksessa ja hahmottelee esimerkinomaisesti Herbartin ontologiaa. Jouni Peltonen esittelee empiiris-analyyttista (esimerkiksi Brezinka) teoriamallia kehitysvaiheineen ja saa kysymään, mitä me oikeas- taan tarkoitamme teorialla kasvatustieteessä. Asko Karjalainen esittelee Oulun koulun lähtökohtien kanssa yhteensopivan tutkimusmenetelmän, niin sanotun objektiivisen hermeneutiikan. Juha Suoranta, oululaisten vanha kiistakumppani menetelmäkeskustelussa, kertoo menetelmämuotien aalloista amerikkalaisessa tiedeyhteisössä. Pertti Kansanen pohdiskelee syitä kasvatustieteen huonoon maineeseen niin Yhdysvalloissa kuin meilläkin.

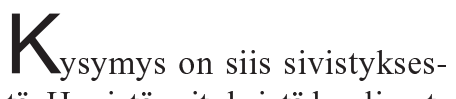
tä. Hyvistä esityksistä huolimatta jäin kaipaamaan jotakin. Aivan kuten teologia vaatii parikseen demonologian pitäisi sivistymisen tarkastelua täydentää vastakkaisella prosessilla, toisin sanoen barbarisoitumisella. Onko tämä aikakausi otollinen nimenomaan sivistymiselle ? Vai sen vastakohdalle?

Kaiken kaikkiaan teos on lähestulkoon parasta kasvatustieteellistä teoretisointia, mitä minä olen kotimaisilla kielillä lukenut. Olisiko kirja liian vaikea kurssikirjaksi ? Ehkä se paremmin pääsisi oikeuksiinsa seminaarikeskustelun lähtökohtana.

JYRKI HILPELÄ 